\title{
AFFIRMATIVE ACTION AND THE REMEDIAL SCOPE OF TITLE VII: PROCEDURAL ANSWERS TO SUBSTANTIVE QUESTIONS
}

\author{
MARSHALl J. WaLTHEW $\dagger$
}

Richard Kluger described Brown v. Board of Education ("Brown $\left.I^{\prime \prime}\right)^{1}$ as a triumph of "simple justice" over technical legal reasoning. ${ }^{2}$ Ultimately, and despite the critical jurisprudential and socio-political furor that has accompanied that landmark decision and its progeny, the simple justice theory remains the overarching justification for the Court's active role in the struggle for racial equality in America. ${ }^{3}$ As the history of the school desegregation movement suggests, however, it is easier to identify the need for simple justice than to administer a remedy to achieve it. ${ }^{4}$ This appears to be so, largely because reality has

† B.A. 1977, Haverford College; J.D. Candidate 1988, University of Pennsylvania.

1347 U.S. 483 (1954).

2 See generally R. KLUGer, Simple Justice (1976) (discussing Brown within the context of the interaction between law and individuals, society's values, and the emotional component of "justice").

s See generally Spann, Simple Justice, 73 Geo. L.J. 1041 (1985) (arguing that legal reasoning gives way to substantive equitable decisionmaking in hard cases, such as those involving remedies for discrimination).

1 This point was demonstrated when the Court was faced with the task of overcoming resistance to Brown v. Board of Educ., 349 U.S. 294 (1955) ("Brown II'). The subsequent task of applying Brown $I$ and Brown $I I$ grew increasingly complex as the focus of the Court's inquiry shifted from the problem of curing past intentional segregation to that of curing segregation that had more subtle sociological origins. See Milliken v. Bradley, 418 U.S. 717, 752 (1974) (The Court rejected a multidistrict remedy for a single district de jure segregation problem and thus ignored the underlying reality of segregation between predominately white suburbs and a largely black inner city.); Swann v. Charlotte-Mecklenburg Bd. of Educ., 402 U.S. 1, 22-32 (1971) (When faced with segregated school zones, the Court recognized the key problem of student assignment and upheld several remedial measures including creating new attendance zones by pairing noncontiguous areas, busing, and the limited use of racial quotas.); Green v. County School Bd., 391 U.S. 430, 441 (1968) (The Court found the school board's "freedom of choice" plan an insufficient step toward eliminating dual school systems, noting that in three years, no white child chose to attend the all-black school and 85\% of the black children remained in the all-black school.). On the increasing complexity of the Court's task, see also J. Wilkinson, From Brown to Bakke-The SUPreme Court AND Social InTEgRation: 1954-1978, at 308 (1979) (The author concludes that "[s]chool integration has taught us . . . how much eludes the American capacity to reshape."); Fiss, School Desegregation: The Uncertain Path of the Law, 4 PHIL. \& PuB. AfF. 3, 3-4 (1974) (dual phenomena of racial assignment to schools and demographic patterns of segregation created a school system that the Court held unlawful; however, it never decided whether one of these phenomena alone would violate the 
frequently dictated that effective remedies in racial discrimination cases require the Court to eschew traditional notions about the limit of its own remedial discretion. These traditional notions center around the twin principles of harm and fault. The Court has viewed itself as free to provide remedies for harm to individuals, and it has usually required that the remedy be predicated on the identification of a culpable party. ${ }^{5}$

The problem facing the Court can be framed in terms of its difficulty in determining whether its proper role is that of social architect or resolver of discrete disputes between parties. This difficulty was apparent in the cases in which the Court struggled to implement Brown,

Constitution, leaving an ambiguity that explains the Court's "sometimes illogical" treatment of the desegregation issue); Goodman, De Facto School Segregation: A Constitutional and Empirical Analysis, 60 GALIF. L. Rev. 275, 436-37 (1972) (After balancing freedom of choiçe against empirical premises that segregated schools harm blacks, the author concludes that voluntary access satisfies constitutional requirements of equal protection.); Gunther, Some Reflections on the Judicial Role: Distinctions, Roots, and Prospects, 1979 WASH. U.L.Q. 817, 819 (remedies in school desegregation cases raise problems concerning administrative, managerial, and legislative functions of the judiciary). Cf. D. Bell, RACE, Racism AND AMERICAN LAw 22-45 (2d ed. 1980) (stressing courts' timidity in regard to sociological segregation and its effects).

- See Comment, Sins of Discrimination: Last Term's Affirmative Action Cases, 100 Harv. L. Rev. 78, 92 (1986) (arguing that the Court has improperly focused on punishment of culpable discriminators rather than providing remedies for victims). The fault principle is at the heart of American common law jurisprudence and is the guiding principle behind the law of negligence and the law of breach of contract, though notions of strict liability have gradually begun to erode this perspective.

The fault principle may be anchored in early efforts by the law to assess criminal behavior, precisely the area where strict liability has made little headway. See, e.g., Kelman, Strict Liability: An Unorthodox View, in 3 ENCYClOPEDIA OF CRIME AND JUSTICE 1516, 1518 (S. Kadesh ed. 1983) (desire to assure that only the blameworthy are punished is central to criminal liability); Kelman, Interpretive Construction in the Substantive Criminal Law, 33 STAN. L. REv. 591, 610-11 (1981) (aversion to strict liability generally represents defense of upper-class and status-quo forces).

Tort law has arguably witnessed the furthest erosion of the fault principle. But even there, the historical inheritance, including the doctrine of res ipsa loquitur, was ambivalent and remained so throughout the maturing of industrial society. Compare Blythe v. Birmingham Waterworks, 156 Eng. Rep. 1046, 1049 (Ex. Ch. 1856) (holding that it would be "monstrous" to hold a public utility liable for damages it did not foresee or intend) with Rylands v. Fletcher, 3 L.R.-E. \& I. App. 330 (H.L. 1868) (even though "free from blame," someone who "acts at his peril" will be liable for consequences). One result was a myriad of balancing and utility tests and frequent reformulation of plastic concepts of causation. Although we have witnessed an expansion of strict liability in tort, a retreat from this expansion is evident. See Sindell v. Abbott Laboratories, 26 Cal. 3d 588, 611-12, 607 P.2d 924, 937, 163 Cal. Rptr. 132, 145 (1980) (adopting manufacturers liability in proportion to market share); Beshada v. Johns-Manville Prods. Corp., 90 N.J. 191, 201, 447 A.2d 539, 548-49 (1982) (rejecting a state-of-the-art defense as essentially a negligence standard, but maintaining a two-pronged balancing standard). These cases suggest the tenacity of common law fault principles. It is therefore not peculiar for the proposition that congealed fault, such as society's racism, justifies remedial strict liability, independent of immediate or particular culpability, to encounter the same type of resistance. 
particularly the cases involving busing as a remedy. ${ }^{6}$

In the desegregation context the Court came to focus on the establishment of some form of intentional misconduct as a predicate for invoking its remedial power. By grounding its freedom to adopt broad social policy remedies in a factual finding of past wrong, the Court was able to fit its approach to desegregation into the traditional model of adjudication. Some, however, found the distinction between de facto and de jure segregation that emerged as the basis of this justification to be arbitrary and not responsive to the social realities of segregation. ${ }^{7}$ In practical terms, however, this doctrine effectively worked to limit drastic remedial intervention unless the defendant could be judicially labeled a wrongdoer.

Despite the doctrinal stabilization that, arguably, was achieved by the de jure/de facto distinction in the desegregation cases, the Court had not fully determined the proper remedial balance between providing effective remedies for discrimination and the traditional judicial principles of fault and harm. ${ }^{8}$ The tension implicit between the intent-

- See supra note 4; see also Grawford v. Los Angeles Bd. of Educ., 458 U.S. 527, 544-45 (1982) (The Court upheld a California amendment to the state constitution providing that state courts cannot order mandatory student assignment or transportation unless a federal court could do so under federal law.); Washington v. Seattle School Dist. No. 1, 458 U.S. 457, 487 (1982) (The Court invalidated on fourteenth amendment grounds a state law preventing, with few exceptions, a school board from requiring any student to attend a school other than that geographically nearest her home.). The Court's initial response was to grant increasing amounts of remedial discretion to the trial courts, see Swann, 402 U.S. at 15, but by the time of Milliken, the Court had retreated, in the face of shifting public opinion, to a position tailored to remedy only the wrong committed. 418 U.S. at 744 . Behind the Court's partial withdrawal was the fear that the exercise of unbridled discretion was leading the court system ever further into territory properly reserved for legislative organs and, correlatively, that the court system's proper role was confined to punishing the guilty and making whole the victims of discriminatory acts. Id. at 738; see also Sedler, Metropolitan Desegregation in the Wake of Milliken, 1975 WASH. U.L.Q. 535; Strickman, School Desegregation at the Crossroads, 70 Nw. U.L. REv. 725 (1975) (noting Milliken's retreat from Keyes v. School Dist., 413 U.S. 189 (1973)).

7 See Dayton Bd. of Educ. v. Brinkman, 443 U.S. 526, 540-42 (1979) (rejecting the requirement to determine the impact of each act of discrimination on current discrimination patterns); Columbus Bd. of Educ. v. Penick, 443 U.S. 449, 454-55 (1979) (relying on findings and conclusions of the district court, which found both prior purpose and overt system-wide discrimination); Keyes v. School Dist., 413 U.S. 189, 22336 (1973) (Powell, J., concurring in part and dissenting in part) (assessing the procedural arbitrariness inherent in the Court's de jure/de facto system).

Development of the doctrine that the fourteenth amendment requires strict scrutiny for purposeful racial discrimination and rationality review if only differential impact can be shown illustrates this tension outside the school desegregation context. See Washington v. Davis, 426 U.S. 229 (1976) (establishing purposeful discrimination requirement for invoking strict scrutiny under the fourteenth amendment). Washington, however, was only the prelude to a debate over types of proof allowable and allocation of the burden of proof in fourteenth amendment cases. See, e.g., Rogers v. Lodge, 458 U.S. 613, 616-22 (1982) (discussing relevant evidentiary factors to determine discrimi- 
based standard developed for cases arising out of the fourteenth amendment ${ }^{9}$ and the effect-oriented analysis permitted under Title VII ${ }^{10}$ suggested, however, that the Court's proper role was far from fixed and that it might vary with the source of the Court's authority. ${ }^{11}$

The issue that would seemingly compel both the public and the Court itself to confront the question of the Court's proper role in remedying the problem of discrimination proved to be the question of affirmative action. Specifically, the Court was faced with judging the validity of class-based affirmative action, particularly the use of racial quotas as a means of achieving integration. ${ }^{12}$

The problems posed by affirmative action are more subtle than those faced in the desegregation context because the wrongdoer/victim duality is more difficult to maintain. In recent cases, the Court has recognized this problem and has focused on the broader issue: whether it is a permissible use of the Court's remedial discretion to allow parties to benefit from remedies tailored to classes rather than individuals, when those parties might not all be able to prove legally that they had been victims of discriminatory conduct by a particular person or institution. Conversely, the Court has also examined whether it is permissible to impose such class-wide remedies at the expense of burdening parties not shown to have been personally at fault. Taken together these issues constitute the concept of reverse discrimination. However, the Court is now more openly addressing the issue of its institutional capacity and

natory purpose); Arlington Heights v. Metropolitan Hous. Dev. Corp., 429 U.S. 252, 270 (1977) (must prove discriminating purpose was a motivating factor in the decision to adopt the challenged rule).

- See, e.g., Arlington Heights, 429 U.S. at 265; Washington, 426 U.S. at 242.

10 Civil Rights Act of 1964, Title VII, 42 U.S.C. $§ 2000$ e (1982). See Franks v. Bowman Transp. Co., 424 U.S. 747, 757-62 (1976) (Although Title VII allows discriminatory effects on employees resulting from a bona fide seniority system, an award of seniority relief can be an appropriate remedy for discriminatory refusal to hire.); Albemarle Paper Co. v. Moody, 422 U.S. 405, 422 (1975) (claim that employer did not breach Title VII in "bad faith" held insufficient reason for denying back pay since Congress aimed legislation at effects rather than motivation of employers' actions); Griggs v. Duke Power Co., 401 U.S. 424, 432 (1971) ("Congress directed the thrust of the Act to the consequences of employment practices, not simply the motivation.").

11 This tension is reflected in the contrast between a vision of the Court as an administrator of strictly neutral principles and a vision of the Court as one of a number of possible tools for achieving social justice. The most eloquent and influential spokesman for the neutral principles view was Herbert Wechsler. See generally Wechsler, Toward Neutral Principles of Constitutional Law, 73 HaRv. L. Rev. 1 (1959). Owen Fiss, among others, has championed the latter viewpoint. See, e.g., Fiss, supra note 4, at 36-39 (1974) (attraction of adherence to abstract principles notwithstanding, stubbornness of social injustice demands Court's engagement).

12 See Regents of the Univ. of Cal. v. Bakke, 438 U.S. 265 (1978); T. O'NeILL, Bakke \& THE Politics of EQUALITY (1985); see also infra notes 18-33 and accompanying text. 
attempting to delineate the parameters of its remedial power in the context of a congressional mandate rather than the broad constitutional dictates of the fourteenth amendment.

This Comment will explore the Court's treatment of affirmative action/reverse discrimination under the fourteenth amendment and Title VII, as revealed by three recent cases: ${ }^{13}$ Local No. 93, International Association of Firefighters v. City of Cleveland, ${ }^{14}$ Local 28 of the Sheet Metal Workers' International Association v. Equal Employment Opportunity Commission, ${ }^{16}$ and Firefighters Local Union No. 1784 v. Stotts. ${ }^{16}$ This Comment will show that the Court is moving toward an analysis that focuses on principles of strict color-neutrality in cases arising under the fourteenth amendment but which gives greater weight to the historical remedial purpose behind Title VII in cases arising under the statute. This approach reflects a proper assessment of the Court's remedial role under two related but different sources of authority.

This Comment will argue, however, that the Court has failed to appreciate adequately the fact that discrimination and reverse discrimination are not substantively identical. ${ }^{17}$ This failure has led the Court to adopt procedural requirements relating to the burden of proving harm at the remedial phase of litigation, which, though seemingly neutral, effectively favor the reverse discrimination plaintiff. To correct this inequity, the Court should, at minimum, restructure proof requirements to put discrimination plaintiffs and reverse discrimination plaintiffs on an equal footing in light of the differing effects of group harm versus individual harm. Specifically, under Title VII, the burden of proving harm at the remedial stage should be shifted to the discriminator to show that plaintiffs were not harmed by its discriminatory conduct.

Part I of this Comment will examine the current status of the Supreme Court's affirmative action doctrine, focusing primarily on the debate over the scope of the Court's authority under Title VII to issue

13 The cases do not specifically deal with the issue of reverse discrimination by name, but all three cases involve predominantly white unions objecting to the institution of affirmative action plans.

14106 S. Ct. 3063 (1986).

15106 S. Ct. 3019 (1986).

16467 U.S. 561 (1984).

17 See infra text accompanying notes 113-16. Justice Stevens, however, has accepted this view. See Wygant v. Jackson Bd. of Educ., 106 S. Ct. 1842, 1870 (1986) (Stevens, J., dissenting) ("II]n striking contrast to the procedural inadequacy and unjustified breadth of the race-based classification in Fullilove v. Klutznick, the race conscious layoff policy here was adopted with full participation of the disadvantaged individuals ...." (citation omitted)). 
class-based relief in situations involving racial discrimination. Part II will evaluate the doctrine and suggest alternative ways of distributing the burden of proof to achieve more equitably the remedial goals of the underlying law.

\section{Development of Affirmative Action Doctrine}

\section{A. The Background}

The decision in Regents of the University of California $v$. Bakke ${ }^{18}$ represented the Court's first attempt to grapple with the notion of reverse discrimination brought about by the use of a quota system. However, the opinion did little more than establish the parameters for the upcoming legal debate. Bakke's challenge to the University of California Davis admissions process most starkly illustrates the conflict between group justice via affirmative action and individual justice premised on the principle of strict race neutrality. ${ }^{19}$ Perhaps because the issues inherent in this conflict present compelling equitable claims on both sides, the Court was badly divided.

Justice Powell's "swing opinion" balanced competing elements of two four-justice pluralities in a delicate compromise: ${ }^{20}$ the decision held that quotas and certain affirmative action plans violate Title VI, ${ }^{21}$ but

18438 U.S. 265 (1978).

19 See Dixon, Bakke: $A$ Constitutional Analysis, 67 Calif. L. Rev. 69 (1979). Dixon stated the conflict as follows:

On the one hand, there is the plea from many blacks for reparations in the form of a substantial approximation to ethnic proportionality in the allocation of scarce social goods. ... On the other hand, a policy of ethnic proportionality that qualifies a person's equality of opportunity has no foundation in our individual-rights focused constitutional tradition; [and] no foundation in the traditional western concept of equal citizenship, a status keyed to personality and not to groups ....

Id. at 74; see also T. O'NEILL, supra note 12, at 6 ("Bakke provoked a national debate over the legal, social, and ethical justifications for preferential treatment of racially disadvantaged groups."); Bell, Bakke, Minority Admissions, and the Usual Price of Racial Remedies, 67 Calif. L. REv. 3, 18 (1979) ("II]t is . . . clear that impressive arguments can be marshalled under the fourteenth amendment and the civil rights statutes either to uphold or to invalidate minority admissions programs.").

${ }^{20}$ On the one hand, Justices Brennan, White, Marshall, and Blackmun were in agreement that Title VI permitted the medical school's quota system. Bakke, 438 U.S. at 328, 335-40. On the other hand, Justice Stevens, with whom then-Chief Justice Burger and Justices Stewart and Rehnquist concurred, expressed the view that the quota system established a two-tier system in violation of Title VI's policy of nondiscrimination. Id. at $408,412-14$.

${ }_{21}$ Civil Rights Acts of 1964, Title VI, 42 U.S.C. $\S 2000 \mathrm{~d}-1$ to $-4,-6$ (1982). Section 601 of Title VI provides that "[n]o person in the United States shall, on the ground of race, color, or national origin, be excluded from participation in, be denied the benefits of, or be subjected to discrimination under any program or activity receiv- 
the more stringent view that Title VI was color blind, in the sense that it forbade the use of racial classifications as a factor in admission decisions, was not endorsed. ${ }^{22}$ Instead the opinion affirmed that racial classifications might properly be used by entities receiving enough government funds to come within the ambit of Title VI, ${ }^{23}$ though the conditions for such use remained far from clear. Having decided that the University's plan violated Title VI, the Court was left with the task of fashioning a remedy for Bakke. The Court decided that Bakke should be admitted to the program unless the University could show that, even absent the discriminatory effect of its minority preference plan, Bakke would not have been admitted. ${ }^{24}$ The Court easily could have required Bakke to prove that, but for the quota system, he would have been admitted. Surely the Court realized that, given the onerous task of carrying such a burden, its very assignment would effectively determine the remedial issue. Implicit, therefore, in the Court's decision was the determination that fairness dictated that a plaintiff who had succeeded on the liability issue not be denied a remedy on account of a court-fashioned rule of proof. It is important to note, however, that the Court has not always been consistent in assigning the burden of proving actual harm; in cases furthering the underlying aims of antidiscrimination legislation, the Court often has placed the burden of proof on the victims. ${ }^{25}$

In light of the ambiguity of the Bakke holding, cases soon arose testing the validity of quotas in other contexts. Two leading cases began to delimit a sphere of acceptability for the use of quotas under federal law. First, Fullilove v. Klutznick ${ }^{26}$ indicated that judicial tolerance of quotas would increase when they were applied pursuant to a congressional mandate. ${ }^{27}$ The Court's decision in Fullilove was somewhat simpler than in Bakke because the statute challenged in Fullilove unequivocally endorsed an affirmative action plan to guarantee that a percentage of federal contracts would be set aside for minority

ing Federal financial assistance." 42 U.S.C. $\$ 2000 d$ (1982).

${ }_{22}$ Bakke, 438 U.S. at 319-20 (Powell, J., plurality); see also Blasi, Bakke as Precedent: Does Mr. Justice Powell Have a Theory?, 67 Calif. L. Rev. 21, 33 (1979) ("The key feature of Justice Powell's analysis is . . . that racial preferences may lawfully be employed . . . , but only if the consideration of race forms merely one [criteria in a diversified application]."); Dixon, supra note 19, at 74 ("The attraction of the Powell compromise to many is that it sets forth neither a notion of strictly colorblind individualism nor a notion of large-scale reparations and race preferences based on the loose concept of societal discrimination.").

23 Bakke, 438 U.S. at 321-24.

24 Id. at 320.

${ }^{23}$ See infra notes 34-100 and accompanying text.

26448 U.S. 448 (1980).

27 Id. at 482 . 


\section{businesses. $^{28}$}

The tougher question and the focus of this Comment is determining the scope of the Court's remedial power under the far-reaching civil rights legislation embodied in Title VII. In United Steelworkers $v$. Weber, ${ }^{29}$ the Court faced this issue for the first time, initiating the process with which this Comment is concerned. Weber tentatively broadened the scope of Fullilove by holding that affirmative action hiring quotas voluntarily adopted by employers did not constitute illegal (reverse) discrimination under Title VII. ${ }^{30}$ The Court reasoned that the prohibition against racial discrimination embodied in Title VII must be read against the backdrop of the historical exclusion of blacks from higher-paid, higher-skilled jobs and the congressional intent of reversing this trend. ${ }^{31}$ It concluded that such a reading could only lead to endorsement of the challenged plan.

Despite the Court's tendency to support class-based remedies for racial discrimination, the allegedly color blind reverse discrimination arguments continued to command the attention of the Court, as indicated by strong dissents in both Fullilove and Weber. ${ }^{32}$ These arguments would in fact prevail when the Court next examined its authority to implement affirmative action plans as a remedy when the employer would not do so voluntarily. ${ }^{33}$

${ }^{28}$ At issue in Fullilove was the "minority business enterprise" provision of the challenged Public Works Employment Act of 1977, Pub. L. No. 95-28, 91 Stat. 116 (1977), which generally required that " $10 \%$ of the federal funds granted for local public works projects must be used ... to procure services or supplies from businesses owned and controlled by members of . . . minority groups." Id. at 453.

${ }_{29}^{29} 443$ U.S. 193 (1979). Weber was a challenge to an affirmative action plan negotiated through the collective bargaining process and designed to eliminate the racial imbalance in the 15 plants owned by Kaiser Aluminum \& Chemical Corporation. Id. at 197-98. Under the plan,

[r]ather than hiring already trained outsiders, Kaiser [was to] establish[] a training program to train its [lesser-skilled] production workers to fill craft openings. Selection of craft trainees was made on the basis of seniority, with the proviso that at least $50 \%$ of the new trainees were to be black until the percentage of black skilled craftworkers . . . approximated the percentage of blacks in the local labor force.

Id. at 199.

so See id. at 197.

s1 See id. at 200-06.

s2 See Fullilove, 448 U.S. at 531 (Stewart, J., dissenting) ("Because of the Court's decision today, our statute books will once again have to contain laws that reflect the odious practice of delineating the qualities that make one person a Negro and make another white."); Weber, 443 U.S. at 222 (Rehnquist, J., dissenting) ("[B]y a tour de force reminiscent not of jurists such as Hale, Holmes, and Hughes, but of escape artists such as Houdini, the Court eludes clear statutory language, 'uncontradicted' legislative history, and uniform precedent in concluding that employers are, after all, permitted to consider race in making employment decisions.").

${ }_{33}$ See Firefighters Local Union No. 1784 v. Stotts, 467 U.S. 561 (1984). 


\section{B. Stotts and the Re-emergence of the Harm/Fault Principle}

Firefighters Local Union No. 1784 v. Stotts ${ }^{34}$ arose when black firefighters, who had previously negotiated a consent decree with the city of Memphis, sought and received judicial modification of the decree. $^{35}$ The original decree had embodied a plan for achieving a better racial balance among Memphis firefighters through use of hiring and promotion quotas. ${ }^{36}$ The negotiated plan seemed to be achieving its goals until financial conditions forced the city to lay off a number of firefighters. ${ }^{37}$ Because the layoffs were implemented according to a citywide seniority system, the provisions of which had not been altered by the decree, they had the effect of negating the affirmative action plan since the layoffs fell disproportionately on the black firefighters, many of whom had been recently hired pursuant to the decree and who consequently had the least seniority. ${ }^{38}$

The Sixth Circuit forbade the city from adhering to the seniority system in such a manner as to contravene the goals of the decree, ${ }^{39}$ but the Supreme Court reversed, holding that section 703(h) of Title VII ${ }^{40}$ protected bona fide seniority systems, such as that in place in Memphis, unless it could be proven that the system was adopted with the intent of effecting a form of discrimination prohibited by Title VII. ${ }^{41}$ Because there had been an express finding by the district court that Memphis' seniority plan had not been adopted because of any discriminatory motive, the consent decree could not work to abrogate this plan. ${ }^{42}$ This conclusion was mandated further by prior Court precedent to the effect that a court acting to modify a consent decree was bound by the remedial limits of the law under which the case would have been litigated if

34467 U.S. 561 (1984).

ss See id. at 565-68.

36 Id. at 565. Specifically, the city agreed to the immediate promotion of 13 black firefighters and to the adoption of a long-term plan "increasing minority representation" at each job-class until representation mirrored the percentage of blacks in the local population. Id.

${ }_{37}$ See id. at 566.

ss See id. at 566-67.

30 Stotts v. Memphis Fire Dep't, 679 F.2d 541, 557-60 (6th Cir. 1982).

10 Section $703(\mathrm{~h})$ provides that

it shall not be an unlawful employment practice for an employer to apply different standards of compensation, or different terms, conditions, or privileges of employment pursuant to a bona fide seniority or merit system ... provided that such differences are not the result of an intention to discriminate because of race, color, religion, sex, or national origin . . .

Title VII of the Civil Rights Act of 1964, 42 U.S.C. $\S 2000 \mathrm{e}-2(\mathrm{~h})$ (1982).

41 Stotts, 467 U.S. at 575, 583.

42 Id. at 567. 


\section{no settlement had been reached. ${ }^{43}$}

Although it is clear that section 703(h) provided good authority for the Court's holding, ${ }^{44}$ the Court's logic in determining that the section applied at all raised serious questions as to the Court's ability to shape class-based remedies via consent decrees. ${ }^{45}$ Nonetheless, if the Court's opinion had confined itself to this line of reasoning, Stotts could have been read as part of the more limited debate on the nature and use of consent decrees. However, Justice White felt compelled to go beyond the safe harbor of section 703(h) and to use Stotts as a platform from which to announce a much broader policy concerning the Court's remedial authority under Title VII. In attacking the Sixth Circuit's view of its authority, Justice White reasoned that the remedial provision of Title VII, section $706(\mathrm{~g}){ }^{46}$ reflects a remedial policy of providing make-

43 See Stotts, 467 U.S. at 576 n.9. Justice White relied on System Fed'n No. 91, Railway Employes' Dep't v. Wright, 364 U.S. 642 (1961), in reaching the conclusion that the underlying statute governed the remedial authority of the Court to approve consent decrees. In Wright, a provision prohibiting closed shops had clearly been altered to permit railway workers to negotiate for such terms. 364 U.S. at 644. Thus, the Court felt free to modify a decree which, in keeping with the earlier version of the statute, had prohibited such arrangements, so that such restrictions would not operate against employees who had not been party to the original decree. See id. at 646-47. It is ironic that Wright stands for the proposition that courts can and must monitor and modify existing decrees in light of changed circumstances, a contention that Justice White had tried to deny earlier in his opinion. See Stotts, 467 U.S. at 574 ("[T] 'scope of a consent decree must be discerned within its four corners . . . .").

it Even commentators critical of the rationale of Stotts are willing to treat it as a defensible application of $\S 703(\mathrm{~h})$, especially in light of International Bhd. of Teamsters v. United States, 431 U.S. 324 (1977). See Note, Race-Conscious Remedies Versus Seniority Systems: Firefighters Local Union No. 1784 v. Stotts, 30 ST. Lours U.L.J. 257, 263-64 (1985) (arguing that Teamsters marked an expansion of the Court's treatment of the seniority system exception); see also Recent Development, The False Alarm of Firefighters Local Union No. 1784 v. Stotts, 70 CoRnELL L. REv. 991, 1001-02 (1985) (arguing that the Stotts holding, though defensible, is limited and could be circumvented by more carefully-drafted consent decrees).

45 Under the Stotts rationale, no consent decree can affect a bona fide seniority plan unless it can be shown that the plan was adopted to effect racial discrimination. See Stotts, 467 U.S. at 577. If the parties seeking the consent decree must establish such intent, the consent decree is no more efficient than full-blown litigation under Title VII.

${ }^{46}$ Section 706(g) provides:

If the court finds that the respondent has intentionally engaged . . . in an unlawful employment practice. . . the court may enjoin the respondent from engaging in such unlawful employment practice, and order such affirmative action as may be appropriate, which may include, but is not limited to, reinstatement or hiring of employees, with or without back pay ... or any other equitable relief as the court deems appropriate . . . No order of the court shall require the admission or reinstatement of an individual as a member of a union or the hiring, reinstatement, or promotion of an individual as an employee, or the payment to him of any back pay, if such individual was refused admission, suspended, or expelled, or was refused employment or advancement or was suspended or discharged for any 
whole relief only to those who have been actual victims of illegal discrimination. ${ }^{47}$ This clarification of the Court's power under Title VII is significant because prior to Stotts, every circuit had read section $706(\mathrm{~g})$ as authorizing race-conscious or group-oriented relief under some circumstances. ${ }^{48}$

The Court's analysis, therefore, marked a victory for the view that Title VII is limited to traditional notions of demonstrable harm and provable fault. Stotts seemed to many commentators to threaten the validity of affirmative action hiring quotas and percentage goals for achieving racial balance in the workplace. ${ }^{49}$ Not only was the section 703(h) exception being read broadly when the employer could claim that a seniority system was implicated, but the very equitable discretion to fashion effective relief, which Title VII seemed to grant the Court in section 706(g), was to be curtailed. By adding a burden of proving actual harm, the Court's opinion could be expected to limit the number of minority litigants eligible to invoke the Court's remedial power and to further limit the scope of that power by prohibiting its exercise if "innocent" parties, such as the white firefighters in Stotts, would thereby be burdened.

However, the fact that the most sweeping portions of the Court's opinion were not logically essential to the narrow result has offered proponents of group-oriented relief a basis for counterattack. Justice Blackmun's dissent, though based on procedural grounds, ${ }^{50}$ recognized

reason other than discrimination on account of race, color, religion, sex, or national origin ....

Title VII, 42 U.S.C. $§ 2000 \mathrm{e}-5(\mathrm{~g})$ (1982).

47 See Stotts, 467 U.S. at 580.

48 See id. at 612 \& n.10 (Blackmun, J., dissenting).

19 See Daly, Stotts' Denial of Hiring and Promotion Preferences for Non-Victims: Draining the "Spirit" from Title VII, 14 Fordham URB. L.J. 17, 102 (1986) (arguing that a proper interpretation of Title VII would allow the statute's broad remedial goals to override affirmative defenses and minor exceptions in cases of conflict); Spiegelman, Court-Ordered Hiring Quotas After Stotts: A Narrative on the Role of the Moralities of the Web and the Ladder in Employment Discrimination Doctrine, 20 HaRv. C.R.-C.L. L. REv. 339, 422-23 (1985) (arguing that the Court's unwillingness to acknowledge the effect that existence within a particular social and/or racial community has on an individual's sense of self-definition limited its view of the issues in Stotts); Note, supra note 44, at 273 (1981) (arguing that the Supreme Court's decision in Stotts imprudently limits the discretion of trial courts to preserve equal employment opportunity gains); Leading Cases of the 1983 Term, 98 HARv. L. REv. 87, 276 (1984) (arguing that Stotts contributes to the anomalous inference that a "person seeking affirmative relief through a consent decree would first have to prove himself an actual victim of the employer's discrimination-proof that can be offered only at the judicial proceeding that the parties are attempting to avoid").

so Justice Blackmun argued mootness in light of the fact that the laid-off employees had been rehired by the time the Supreme Court heard the case. See Stotts, 467 U.S. at 593 (Blackmun, J., dissenting). He also stressed that the majority opinion on 
that, in light of the scarcity of jobs and financial resources in the real world, the task of alleviating the effects of discrimination constitutes a zero-sum game in which some innocent parties are bound to suffer. ${ }^{51}$ If Justice Blackmun's view more correctly describes the social reality, it seems the appropriate questions for the Court to address would not be whether the Gourt may inflict burdens on innocent parties, but rather whether Title VII provides any affirmative guidance as to how those burdens should be apportioned.

The attempt to answer this question has led commentators into the quagmire of the social science approach to the issue of the nature of discrimination and its social effects and ramifications; indeed, Stotts has been examined from this perspective. ${ }^{52}$ The Court, however, has continued to view the sociology of affirmative action through the lens of legal argument, and two recent cases have limited the scope of Stotts without openly repudiating the atomistic jurisprudence that informed Stotts.

The first of these cases, Local 28 of the Sheet Metal Workers' International Association v. EEOC, ${ }^{\mathrm{b3}}$ modified the blanket limitation on class-based relief found in the Stotts interpretation of the scope of the Court's authority under section 706(g). The second case, Local No. 93, International Association of Firefighters v. City of Cleveland, ${ }^{\mathbf{5 4}}$ reasserted the freedom of parties to use consent decrees to fashion their own remedies independent of any remedial limitations that section 706(g) might impose on the Court.

\section{Sheet Metal Workers and the Role of Intent in Defining the Court's Remedial Authority Under Title VII}

In Sheet Metal Workers, the Court faced the question of the valid-

the merits was inappropriate for review of a preliminary injunction, which should properly be judged by the abuse of discretion standard. See id. at 601 .

61 See Stotts, 467 U.S. at 621 (Blackmun, J., dissenting).

52 See, e.g., Spann, supra note 3, at 1076 (arguing that because "legal doctrine is inherently incapable of guarding against subjective values of judges and in fact depends upon subjective values in order to have meaning, [one is tempted to conclude that] it makes sense to . . . simply abandon doctrinal rules and rely instead on direct judicial application of . . . policy objectives"); Spiegelman, supra note 49, at 343 ("Current legal doctrine makes very strange assumptions about human behavior: that people are atomistic individuals who compete against other individuals and neither function in nor care about their relationships with others. These underlying assumptions deny the legal system a vocabulary for the expression of arguments describing a world of interconnection and raise substantial questions about the use of legal doctrine to change underlying social conditions.").

ss 106 S. Ct. 3019 (1986).

s4 106 S. Ct. 3063 (1986). 
ity of a lower court order requiring that a union found guilty of systematically excluding blacks adhere to a schedule of minority hiring based on specified percentage goals. ${ }^{55}$ The union argued that because individuals who had not suffered from the union's discrimination would benefit from such an affirmative action plan, Stotts required invalidation of the district court's order. ${ }^{56}$ The Court upheld the order, reasoning that Stotts only limited the Court's ability to order make-whole relief to individuals shown to have been victims of actual discrimination. The Court, therefore, remained free to fashion affirmative action remedies that were not designed to redress specific harms, but were instead aimed at ameliorating wrongs felt class wide. ${ }^{57}$ In so holding, the Court drew a distinction between prospective affirmative action (Sheet Metal Workers) and retrospective make-whole relief (Stotts) $)^{\mathbf{5 8}}$-a legal distinction that allowed the Court in Sheet Metal Workers to embrace a view of its role vis-à-vis the problem of racial discrimination antithetical to that taken in Stotts.

In reaching this conclusion, the Court reinterpreted section $706(\mathrm{~g}){ }^{80}$ finding, in the first sentence, a clear congressional intent to vest the district courts with broad discretion to award equitable remedies and holding that the limiting language of the second sentence bars relief only if the employer can show that there were nondiscriminatory reasons for rejecting a particular individual. ${ }^{60}$ Thus, in Sheet Metal Workers, the finding of an intentional and egregious pattern of discrimination is used to justify shifting the burden of proof away from the plaintiff as a prerequisite to relief. ${ }^{\text {B1 }}$ In Stotts, on the other hand, this same language was effectively read to require the potential beneficiary of affirmative action to prove that the employer had acted toward him with a solely discriminatory motive. ${ }^{62}$

os See Sheet Metal Workers, 106 S. Ct. at 3026.

${ }^{8}$ See id. at 3048.

67 See id. at 3049-50.

58 See id. at 3031.

s8 See supra note 46.

${ }^{60}$ See Sheet Metal Workers, $106 \mathrm{~S}$. Ct. at 3035 . The purpose of $\S 706(\mathrm{~g})$, to permit the Court to remedy discrimination while leaving employers free to exercise their business judgment as to the particular qualification of individuals, suggests a direct analogy to $\S 8(\mathrm{a})(3)$ of the National Labor Relations Act, 29 U.S.C. § 158(a)(3) (1982). See Speigelman, supra note 49, at 378.

It is ironic that in all three cases under consideration in this Comment, the parties opposing group relief were unions, which have historically been the greatest recipients of legislative and judicial solicitude for remedies geared toward regulating the relations of groups at the expense of individual rights. See J.I. Case Co. v. NLRB, 321 U.S. 332, 335-36 (1944) (establishing the exclusivity of the collective bargaining agreement in preference to individually negotiated work contracts).

61 See Sheet Metal Workers, 106 S. C. at 3031.

${ }_{62}$ See supra notes 39-49 and accompanying text. 
The Court is essentially defining a procedural matrix within which to exercise its discretion. The differing results in Stotts and Sheet Metal Workers are primarily justified by the absence of a discriminatory motive in the former case and the presence of a finding of intentional discrimination in the latter. The two cases taken together effectively apply the intent-based constitutional standard for determining the scope of the Court's remedial power, whereby the degree of fault attributable to the defendant governs the Court's willingness to impose intrusive remedies. When considering the seniority system exception, such as the one at issue in Stotts, the language of section 703(h) clearly supports such a construct: section 703(h) embodies a statutory bias in favor of bona fide seniority systems. The language of section $706(\mathrm{~g})$, however, still leaves open the question of who has the burden of establishing the requisite intent. ${ }^{83}$ In contrast, when considering the application of prospective quotas, the reasonableness of the Court's adoption of an intent standard in light of the ambiguous remedial directive in section $706(\mathrm{~g})$ is not so obvious. ${ }^{64}$

Given the divergent opinions of Stotts and Sheet Metal Workers, it would be unrealistic to expect affirmative action doctrine to be written in stone. Consequently, no permanent solution to the Court's role regarding affirmative action under Title VII has emerged from this debate to date. One can, however, conclude that the Court's concern with establishing the employer's intent as a predicate for certain types of affirmative action indicates that the Court may treat the problem of harm to innocent parties as a more serious threat to the Court's legitimacy than the possibility of windfall benefits to undeserving plaintiffs. More concretely, the Court's attitude is that affirmative action hiring quotas are permissible but that layoffs implicate interests upon which Title VII is not ordinarily permitted to infringe. ${ }^{65}$

\section{Local 93 and the Freedom of Parties to Adopt Affirmative Action Remedies Through Consent Decrees}

The limitations that Stotts prescribed for courts participating in consent decrees are ultimately more troubling for the future of affirmative action than the narrow reading of section $706(\mathrm{~g}) \cdot{ }^{66}$ Section $706(\mathrm{~g})$

Bs See Sheet Metal Workers, 106 S. Ct. at 3024; Stotts, 467 U.S. at 563; supra note 46.

64 See infra notes 109-39 and accompanying text.

${ }_{65}$ This differentiation between quotas and layoffs is more clearly expressed in Wygant v. Jackson Bd. of Educ., 106 S. Ct. 1842, 1851 (1986). See infra notes 103-05 and accompanying text.

${ }^{B в}$ See Kahn \& Moorehead, Stotts: Death Knell of Affirmative Action or Wishful 
defines the Court's power to impose remedies subsequent to litigation; to read it as governing and limiting the actions of private parties seeking to avoid litigation looks suspiciously like the very sort of judicial intrusion into the private sphere that Stotts sought to curtail. Such a reading undermines a fundamental goal of Title VII: voluntary compliance with the principle of nondiscrimination. ${ }^{67}$ But this reading perhaps resulted from the Stotts Court's imprecise notion of the nature of a consent decree. ${ }^{68}$

In contrast, an acceptance of the preeminence of the principle of voluntary compliance together with a clearer notion of the function of consent decrees are both in evidence in Local 93.69 On facts remarkably similar to Stotts, black firefighters sued the city of Cleveland under Title VII, alleging discriminatory hiring and promotion practices that were partially the result of intentional manipulation of the city's seniority points system. ${ }^{70}$ The parties agreed to a plan mandating promotions for certain minority firefighters and temporary suspension of the seniority system. ${ }^{71}$ The district court, over the objection of the intervening union, approved the consent decree. ${ }^{72}$

An affirmative action plan requiring promotion of nonsenior minority employees despite the provisions of a preexisting seniority system and the consequent possibility that innocent nonminority employees might lose their jobs if layoffs became necessary, would clearly seem to violate the holding in Stotts. ${ }^{73}$ A majority of the Court felt otherwise and upheld the lower court's approval of the decree. ${ }^{74}$ The Court

Thinking by the Reagan Administration?, 8 CoRP. L. REv. 251, 259 (1985) ("[T]he Justice Department has recently expanded its attack against affirmative action by challenging not only consent decrees negotiated by other parties but also consent decrees that the Justice Department itself had previously negotiated, approved, and signed."). Certainly, in the wake of Stotts, the Attorney General's Office felt free to discourage and restrict agents of the federal government in their negotiation of consent decrees. See Memorandum from Edwin Meese III, Attorney General, to All Assistant Attorneys General \& All United States Attorneys 1 (March 13, 1986) (Department Policy Regarding Consent Decrees and Settlement Agreements) (adopting guidelines "designed to ensure that litigation is terminated in a manner consistent with the proper roles of the Executive and the courts") (on file with the University of Pennsylvania Law Review).

${ }^{87}$ This is evident in the EEOC Guidelines, which specify that "Congress strongly encouraged employers . . . to act on a voluntary basis to modify employment practices and systems which constituted barriers to equal employment opportunity . . . ." Local 93, 106 S. Ct. 3063, 3072 (quoting EEOC Employment Selection Procedures Guidelines, 29 C.F.R. \$ 1608.1(b) (1985)).

\footnotetext{
${ }^{68}$ See supra notes $39-45$ and accompanying text.

Se See Local 93, 106 S. Ct. at 3076-77.

70 See id. at 3066-68.

71 Id. at 3068.

72 Id. at 3070 .

73 See supra note 49 and accompanying text.

74 See Local 93, 106 S. Ct. at 3080.
} 
reached the opposite position from that articulated in Stotts by stressing the strength of the policy favoring voluntary settlements underlying the grand design of Title VII. ${ }^{78}$ Since the same policy presumably would operate on the facts in Stotts, the Court must have depended on a difference in the procedural postures of the two cases to justify its different characterization of the nature of consent decrees. That difference is the fact that Stotts involved a unilateral request to secure court modification of a decree, while Local 93 involved the original issuance of the decree. $^{76}$

In Stotts, although the Court did not resolve clearly the tension between the dual nature of consent decrees as contracts and court orders, the holding in that case depends on a view that treats modification of a decree as a court order. ${ }^{77}$ As such, section 706(g) was authoritative, and the Court proceeded to interpret it as a proscription to the requested modification. Justice White's original impulse to decide Stotts on the ground that Court authority was limited to effecting purposes and aims found within the "four corners" of the decree, however, led the Court to conclude in Local 93 that the consent decree was primarily a voluntary agreement rather than a court order and thus not subject to the limits on the Court's remedial authority under section 706(g) ${ }^{78}$ Therefore, because the parties thought to include the seniority plan within the terms of the decree and no modification was requested, the plan embodied in the decree was allowed to stand, even though it conflicted with the seniority system established in the city's agreement with the union. ${ }^{79}$ The Court opined that the rights of third parties such as the union were not unduly impinged upon by the agreement because the union had been given an opportunity to present its views at the proceedings in which the court considered the validity of the decree. Furthermore, the union remained free in an action of its own to assert any claims that it might have against the city for contravening its prior agreements. $^{80}$

The two dissenting opinions were disposed to support the union's claim. Justice White's dissent reasserted his belief that the Court could

${ }^{76}$ See id. at 3074-75.

${ }^{76}$ See id. at 3076-79.

77 See supra note 43 and accompanying text.

${ }^{78}$ See Local 93, $106 \mathrm{~S}$. Ct. at 3075-76. It is worth noting that Justice Brennan's majority opinion does not concede that the plan embodied in the consent decree would be outside the scope of the Court's remedial power. See id. at 3072. Clearly the debate over the limits of $\S 706(\mathrm{~g})$, though not strictly at issue here, is not settled. See id. at 3072 n.7.

79 See id. at 3079.

so See id. at 3079-80. 
not sanction any remedies benefiting individuals who had not proven harm at the expense of individuals who had not been proved guilty of discrimination. ${ }^{81}$ Justice White did, however, agree that such affirmative action relief would be supportable by the Court if the "necessary factual predicate" had been proven. ${ }^{82}$ Justice White's approach mentions Stotts only in passing and ignores the question of proper judicial characterization of a consent decree. It relies instead on the belief that, except under the circumstances described in Sheet Metal Workers, Title VII is a color-neutral statute. ${ }^{83}$ Taken literally, Justice White's notion of the necessary factual predicate would emasculate the consent decree as a remedial device in discrimination cases because parties enter into consent decrees to avoid the time, expense, and uncertainty of litigation over just such matters as the necessary factual predicate. ${ }^{\mathbf{8 4}}$

Justice Rehnquist, joined by Chief Justice Burger, also dissented, relying on Stotts and the language of section $706(\mathrm{~g})$ to find the decree impermissible. Justice Rehnquist agreed with Justice White that the Court, in deciding Title VII cases, should limit itself to resolving discrete disputes on the basis of proven harm and fault. ${ }^{85}$ Justice Rehnquist, however, challenged the Court's analysis of the settlement policy behind Title VII based on his review of the legislative history of Title VII in general and section $706(\mathrm{~g})$ in particular. ${ }^{86}$ Comparing the majority's treatment of the legislative history with his own, Justice Rehnquist was forced to admit that attempts to pin down a legislative intent for such a complex statute are inconclusive at best. ${ }^{87}$

s1 See id. at 3081-82 (White, J., dissenting).

${ }^{82}$ Id. (White, J., dissenting). For Justice White, that factual predicate is a finding of egregious intentional discrimination on the part of the employer. See id. (White, J., dissenting). Justice White ignores the simple question of why the parties seeking the consent decree should have to prove the same facts that they would had they gone to trial.

83 See id. at 3081-82 (White, J., dissenting).

B4 See C. Sullivan, M. Zimmer \& R. Richards, Federal Statutory Law of Employment Discrimination 848-49 (1980) (explaining that consent decrees eliminate uncertain, costly, and protracted litigation); Comment, Employment Discrimination-Affirmative Action Remedies-Consent Decrees Not Orders of the Court Within the Ambit of Section 706(g) of Title VII, 18 RuTGERS L.J. 493, 495 (1987) (noting that consent decrees are widely used to avoid costly litigation in discrimination cases arising under Title VII).

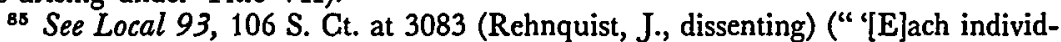
ual must prove that the discriminatory practice had an impact on him." (quoting Stotts, 467 U.S. at 579)).

${ }^{86}$ See id. at 3085-87 (Rehnquist, J., dissenting).

87 See id. at 3087. William Eskridge provides an excellent analysis of the feasibility of using legislative intent as a judicial guide. See Eskridge, Dynamic Statutory Interpretation, 135 U. PA. L. REv. 1479 (1987). Eskridge argues that statutes must be interpreted dynamically over time to accommodate changes in social, political, and legal circumstances and values. See id. at 1483-84 ("subsequent evolution of the statute and 
Ultimately, Justice Rehnquist's dissent hinges on his characterization of the consent decree as an order of the court, subject to the limitations of section 706(g) as interpreted in Stotts, rather than as a voluntary, contractual agreement between the parties. ${ }^{88}$ Both the majority and the dissent cite to a definition in Moore's Federal Practice as authority for their competing views of consent decrees. ${ }^{89}$ The absurdity of significant cases being decided through the exegesis of a secondary source definition is manifest. This semantic debate is made even more absurd by the fact that any contract, even a commercial one, entitles either side to invoke the enforcing power of a court, including, under proper circumstances, the power of modification. ${ }^{90}$

The practical consequences of the attitudes taken toward consent decrees by the opposing opinions are, however, more significant than the debate itself would suggest. Justice Rehnquist's opinion seems to imply that, by entering into the consent decree, plaintiffs forfeit their opportunity to prove their allegations and that the allegations must now be treated as if they had been disproved. ${ }^{91}$ This attitude would make it risky indeed to enter into a consent decree unless one had no hope of proving one's allegations at trial. But under these circumstances, the opposing party would be unlikely to agree to a settlement. Such an attitude certainly would tend to negate the litigation-reducing function of consent decrees. Justice Rehnquist refuses to concede that, as the

its present context" are most important when the statutory text is unclear and the initial legislative purpose has been "overtaken by subsequent changes in society and law"). He concludes that the position of the Court in Sheet Metal Workers and the dissent in Stotts that $\$ 706(\mathrm{~g})$ allows flexible judicial relief is strongly supported by the text of the statute, the evolution of Title VII, and the changed social circumstances. See id. at $1495-96$ \& n.65.

${ }^{88}$ See Local 93, 106 S. Ct. at 3087 (Rehnquist, J., dissenting) ("WW]hile the legislative history may be fairly apportioned among both sides, the language of the statutes is clear. No order of the Court shall require promotion of an individual whose failure to receive promotion was for a reason other than discrimination prohibited by the statute.").

${ }^{80}$ Compare Id. at 3077 (quoting 1B J. MOORE, W. TAggart \& J. Wicker, MoORE's FEderal PRACTICE If 0.409[5] (1984)) (building the argument that a federal court is not barred from approving a consent decree providing broader relief than could be given at trial) with id. at 3084 (Rehnquist, J., dissenting) (quoting 1B J. MOORE, W. TAGgarT \& J. Wicker, supra, at $\Uparrow 0.409[5]$ ) (demonstrating that an entered consent decree is an adjudication). If Moore's were indeed mandatory authority, Justice Rehnquist would have the better of the argument. The definition quoted by Justice Rehnquist, but only partially quoted by Justice Brennan, concludes that despite its contractual appearance, a consent decree is fundamentally an act of adjudication.

${ }^{80}$ See 1 A. Corbin, Corbin on Contracts $\$ 3$ (1963) (A contract is said to be an agreement enforceable at law.); E. FarnsworTh, ConTracts $\S 4.1$ (1982) (When a court places limits on the enforceability of a contract, it must balance the merits of "enforcing the bargain as made" against an interest in the "prevention of unfairness."). 91 See Local 93, 106 S. Ct. at 3084 (Rehnquist, J., dissenting). 
majority seems to assume, the consent decree could just as easily be read as a tacit admission by the city that the allegations were true and that avoiding the expense and publicity of a trial were worth whatever concessions the decree might entail. This latter reading seems more appropriate since both the majority opinion ${ }^{92}$ and Justice O'Connor's concurrence $^{93}$ indicate that the city's choice does not free it from litigation, but rather leaves it subject to any claims the union may be able to assert under the fourteenth amendment.

The overall effect of the majority opinion is to permit the city to choose which of two potential suits it wishes to defend. Rationally, the city should choose to settle the stronger of the two suits to gain the advantage of choosing which opponent to face in court and thus possibly avoid litigation if the union decides its claim is not worth pressing. On the other hand, Justice Rehnquist's approach, as well as that of Justice White, would encourage parties to throw all their resources into litigation, and, given the burden of proof framework established by Stotts and Sheet Metal Workers, such litigation would have high stakes indeed. ${ }^{94}$ Interestingly enough, in light of the decision in Sheet Metal Workers, had the plaintiffs in Local 93 proved all of their allegations at trial, the district court could have ordered relief substantially similar to that provided in the decree.95 Thus, the remedy applied in Local 93, if administered via an injunction, could be consistent with Stotts without holding that the court had exceeded its remedial authority. If the primary purpose of a consent decree is to bypass the need for litigation on the merits, it is counterintuitive to require litigation on the merits as the prerequisite for a privately negotiated remedy.

It is axiomatic, of course, as Justice Rehnquist points out, that the parties cannot agree to bind third parties and that the decree cannot compel action that violates the law. ${ }^{96}$ As the principle cases discussed in this Comment demonstrate, the ability of the Court to employ affirmative action remedies is far from settled. However, the consent decree in Local 93 was not a clear violation of Title VII; there was no ground for invalidating the decree on that score. Moreover, as the majority points out, the decree did not bind the union, but rather left it with a

${ }^{92}$ See id. at 3075 n.11.

${ }^{93}$ See id. at 3080 (O'Connor, J., concurring).

or See Stotts, 467 U.S. at 578-79; Leading Cases of the 1983 Term, supra note 49 , at 276; supra text accompanying note 49.

os The limiting aspect of $\S 703(\mathrm{~h})$ would not apply if the seniority system were intentionally employed in a discriminatory manner. See Title VII, 42 U.S.C. $\$ 2000 \mathrm{e}-$ 2(h) (1982).

${ }^{96}$ See Local 93, 106 S. Ct. at 3083-84 (Rehnquist, J., dissenting). 
variety of colorable legal claims. ${ }^{87}$ Ultimately then, Justice Rehnquist's opinion is based on the unspoken belief that the principle of avoiding harm to innocent parties is an overriding one. In this case, however, since the city is likely to have committed wrongs against at least one, if not both of the parties, the effect of assigning such importance to that principle is to subrogate the principle that the court's purpose is to punish wrongful conduct. Procedurally, the Rehnquist construction functions like a form of interpleader, pitting the plaintiffs against the union in a pseudo-dispute, which diverts attention from the fact that whatever harm either side has suffered is traceable to the city's discriminatory conduct. ${ }^{98}$

Perhaps Justice Rehnquist is anticipating the potential paradox that could arise if, after the union pressed its claims in a separate proceeding, the Court determined that the only effective remedy would involve abrogation of the affirmative action plan applied in the decree, thus setting off a possibly endless chain of litigation. Since the union might not prevail on its claims, or the Court might decide on a remedy that did justice to both parties' interests, the mere possibility of that occurrence is a slender reed upon which to base a decision with such important ramifications.

In a more practical vein, it appears that the Court has rejected the hierarchy of values expressed by Justice White and implicitly used by Justice Rehnquist. The decisions in Sheet Metal Workers and Local 93 come close to repudiating Stotts without expressly overruling it. They do so while maintaining a certain consistency of logic, even though the distinctions between the Court's authority to order make-whole relief as opposed to prospective affirmative action and between entry of a consent decree and modification of a consent decree seem almost trivial grounds on which to reassert the primacy of the Court's prophylactic remedial authority under Title VII. ${ }^{98}$

Lest it be thought that these cases point the Court in a fixed direction with regard to affirmative action, the Court's decision in Wygant $v$. Jackson Board of Education ${ }^{100}$ clearly indicates that the value struc-

97 See id. at 3075 n.11.

${ }^{98}$ The ultimate goal of interpleader, however, is not to exonerate the defendant but to allow her to maximize efficiency by requiring all parties to whom she is potentially liable to settle among themselves the question of which one has the valid claim. See Black's LaW Dictionary 733 (5th ed. 1979).

${ }^{99}$ Justice White's dissent in Local 93, as well as his majority opinion in Stotts, at least have the virtue of openly framing the interpretive debate as one between principles of neutrality and remedial efficacy. See Local 93, $106 \mathrm{~S}$. Ct. at 3081-82 (White, $\mathrm{J}$, dissenting); supra text accompanying notes 81-84.

100106 S. Ct. 1842 (1986). 
ture expressed in Stotts remains an important factor in the Court's thinking.

\section{E. Wygant and Closing the Circle}

Wygant represented the culmination of a long series of interactions between a school board and its teachers in which the school board, reacting to pressure from the black community, had attempted to assure black representation in the labor force. In Wygant, the defendant school board had agreed to layoffs affecting senior white employees in order to help preserve the ameliorative effects of an affirmative action plan. ${ }^{101}$ Unlike the reverse discrimination plaintiffs previously discussed in this Comment, the white employees brought their cause of action under the fourteenth amendment in addition to Title VII, compelling the Court to rely on its own notions of constitutional limits on the exercise of remedial discretion rather than on the ambiguous mandate of Title VII. ${ }^{102}$ The Court held that the affirmative action plan violated the Constitution because it impermissibly punished individuals who were not at fault for the original acts of discrimination. ${ }^{103}$ In essence, this result implies that the Constitution embodies a color-neutral attitude toward discrimination that does not look beyond the fact of the use of racial classifications to the real-world goals of remedying discrimination. ${ }^{104}$ Specifically, the Court asserted that layoffs could be treated differently than hiring quotas or goals on the basis of the more tangible interest in preserving an established job as against the mere hope of employment in the future. ${ }^{105}$

The Court acknowledged that the goal of alleviating the effects of prior proven discrimination might rise to the level of a compelling state interest but avoided a decision on that issue by holding that the affirmative remedy was not sufficiently narrowly tailored. ${ }^{106}$ The Court discounted the school board's voluntary admission that it had been guilty of past discrimination on the grounds that the school board had denied

101 Id. at $1845-46$.

102 See id. at 1846-47.

103 Id. at 1851-52.

104 See id. at 1848 ("No one doubts that there has been serious racial discrimination in this country. But as the basis for imposing discriminatory legal remedies that work against innocent people, societal discrimination is insufficient and over expansive.").

${ }^{105}$ Id. at 1851-52.

${ }^{106}$ See id. at 1852; see also Sullivan, Sins of Discrimination: Last Term's Affirmative Action Cases, 100 Harv L. Rev. 78, 87 (1986) ("While stating that a narrowly tailored remedial purpose might have been compelling, Justice Powell wrote for the plurality that neither the more forward-looking nor the more broadly 'remedial' purpose advanced by the school district would do."). 
those allegations in prior proceedings and the district court had found no such discrimination. ${ }^{107}$ In essence, the decision punishes the plaintiffs in the original discrimination action for failing to prove what their chosen mode of proceeding, settlement, did not require. ${ }^{108}$

This is effectively the result sought by the dissenting opinions in Local 93. Although Wygant applies only to state actors subject to the fourteenth amendment, the decision creates a curious tension between Title VII and the Constitution. Thus, plaintiffs litigating against state defendants must be aware that any victories involving affirmative action remedies may be subject to subsequent attack, and state-actor defendants will be less likely to settle unless they feel that they would rather face a reverse discrimination suit.

\section{An Evaluation of the Emerging Doctrine}

The cases discussed in this Comment can be seen as attempts to reconcile competing principles of adjudicatory authority as they apply to a complicated sociological problem. The principles at play are the effective remedial administration of statutory and constitutional mandates versus the avoidance of harm to innocent parties. Wygant $v$. Jackson Board of Education ${ }^{109}$ reaffirms the assertion in Firefighters Local Union No. 1784 v. Stotts ${ }^{110}$ that the latter principle will normally prevail over the former when statutory language does not provide clear answers.

In practical terms, these cases demonstrate that the Court is mov: ing toward a compromise on affirmative action that allows race-conscious relief in the form of quotas and hiring goals, but forbids raceconscious relief that entails actual harm to individuals who did not participate in the institutional discrimination being remedied. ${ }^{11}$ At first blush this compromise seems rational, especially considering the special status accorded seniority systems by section 703(h). The result seems justified because a plan involving layoffs creates visible victims of reverse discrimination whose claim to a remedy appears more concrete

${ }^{107}$ See id. at 1849 \& n.5 ("Both courts concluded that any statistical disparities were the result of general societal discrimination, not of prior discrimination by the Board.").

${ }^{108}$ See id. at $1848-49$.

109106 S. Ct. 1842 (1986).

110467 U.S. 561 (1984).

111 The most recent Supreme Court decisions on affirmative action confirm this trend without altering the Court's analysis of harm. See Johnson v. Transportation Agency 107 S. Ct. 1442, 1457 (1987) (upholding preferential hiring and promotion policy for women); United States v. Paradise, 107 S. Ct. 1053 (1987) (upholding preferential promotion policy for black state troopers in Alabama). 
and more pressing than that of an unidentified minority member who will benefit from a hiring quota or that of a minority employee who may have been hired to the exclusion of a similarly, or better, qualified white. ${ }^{112}$

This analysis, however, ignores the fact that the two types of discrimination are qualitatively different. Reverse discrimination is discrete and does not follow the affected individual into her other endeavors, whereas original discrimination is symptomatic of widespread social attitudes that have affected minority individuals in varying degrees at all stages of their lives. ${ }^{113}$ Furthermore, reverse discrimination does not possess the element of scienter ${ }^{114}$ that lies invidiously at the core of all racial discrimination. ${ }^{115}$ Though it may indeed be small solace to a person laid off as the result of an affirmative action program, the discriminatory act is not motivated by hatred of that person's race or a failure to perceive the value of that person's individual qualities without the distorting bias of racial stereotyping. Recognition of this

112 See, e.g., Fallon \& Weiler, Firefighters v. Stotts: Conflicting Models of Racial Justice, 1984 SuP. CT. REv. 1, 68 ("There are important differences between racebased hiring preferences and racial quotas that eviscerate seniority rights. The latter, when causing senior whites to be evicted from their jobs, impose an excessive burden on the displaced individuals. By comparison, because hiring quotas exact a lesser cost, preferences at the entry level ought to be upheld.").

113 See, e.g., Kennedy, Persuasion and Distrust: $A$ Comment on the Affirmative Action Debate, 99 HARv. L. REv. 1327, 1328 (1986) (concluding that affirmative action "should generally be retained as a tool of public policy because . . . it is useful in overcoming entrenched racial hierarchy"); Renfrew, Affirmative Action: A Plea for a Rectification Principle, 9 Sw. U.L. REv. 597, 609 (1977) ("We do not . . . know precisely how the distribution of societal advantages between blacks and whites might differ ... had de jure racial prejudice proved amenable to rapid extinction. But we know that the composition of our professions would be very different . . ." ); Wasserstrom, Racism, Sexism, and Preferential Treatment: An Approach to the Topics, 24 UCLA L. REv. 581, 618 (1977) ("[T]he system of racial and sexual superiority . . . was an immoral one in that it severely . . restricted the capacities, autonomy, and happiness of those who were members of the less favored categories."). But see, e.g., A. BICKEL, THE MORALITY OF CONSENT 133 (1975) (arguing that the racial quota is "a divider of society, a creator of castes"); Abram, Affirmative Action: Fair Shakers and Social Engineers, 99 HARV. L. REv. 1312, 1322-23 (1986) ("[T]he social engineers" approach exacerbates divisions within society by implicitly assuming that white males .. are the undeserving beneficiaries of special privileges at the expense of all others." (footnote omitted)); Posner, The De Funis Case and the Constitutionality of Preferential Treatment of Racial Minorities, 1974 SuP. Cr. REv. 1, 24 ("[E]mpirical inquiries into the effects of particular forms of discrimination on the affected group[] . . . [are] intractable and would leave the field open to slippery conjecture.").

114 See supra notes 40-44 and accompanying text; see, e.g., Regents of the Univ. of Cal. v. Bakke, 438 U.S. 265, 361-62 (Brennan, J., concurring in part and dissenting in part) (the ostensible purpose of an affirmative action program is to remedy the effects of past racial discrimination).

${ }_{115}$ See, e.g., Washington v. Davis, 426 U.S. 229, 240 (1976) ("IT]he invidious quality of a law claimed to be racially discriminatory must ultimately be traced to a racially discriminatory purpose."). 
fundamental difference between discrimination and reverse discrimination provides an adequate justification for not treating the two phenomena alike. ${ }^{116}$

Wygant and Stotts, however, demonstrate the Court's view that judicial application of the sociological notion of harm must be informed and limited by the traditional notion of individual harm. Since the Court steadfastly refuses to endorse the broad view of the harm caused by discrimination, the question remains whether the balance struck in these cases between the competing notions of harm makes sense in light of the Court's role in administering Title VII. ${ }^{117}$

The Court's treatment appears defective in two respects. The first is that, assuming the Court should take a neutral stance and not distinguish the various types of discrimination, it has not done so. The second is that the historical purpose behind the enactment of both Title VII ${ }^{118}$ and the fourteenth amendment ${ }^{118}$ suggest that facial neutrality is

${ }^{116}$ See, e.g., Ely, The Constitutionality of Reverse Racial Discrimination, 41 U. CHI. L. REv. 723, 727 (1974) (suggesting that "'special scrutiny' is not appropriate when White people have decided to favor Black people at the expense of White people"); Kennedy, supra note 113, at 1329 ("Affirmative action has strikingly benefited blacks as a group and the nation as a whole."); Wasserstrom, supra note 113, at 618 (Blacks and women "do not constitute the dominant social group" and therefore the characteristics of a "fully developed member of the moral and social community" exclude black and female. "Quotas which prefer women or blacks do not add to the already relatively overabundant supply of resources and opportunities at the disposal of white males."). But see, e.g., A. BiCKEL, supra note 113, at 133 ("[D]iscrimination on the basis of race is iliegal, immoral, unconstitutional, inherently wrong, and destructive of democratic society. . . . Having found support in the Constitution for equality, [advocates of racial preferences] now claim support for inequality under the same Constitution."); Abram, supra note 113, at 1318 ("[T] conception of racial justice is both destructive of true racial equality and potentially harmful to society."); Posner, supra note 113, at 25 ("[T] ciple is not no 'invidious' racial or ethnic discrimination, but no use of racial or ethnic criteria to determine the distribution of government benefits and burdens.").

117 See Eskridge, supra note 87 at 1488-96, 1545 (The Court's dynamic interpretation of Title VII in United Steelworkers v. Weber, 443 U.S. 193 (1979), evinces an "evolutive perspective" necessitated by changing concepts of "discrimination."); Sullivan, supra, note 106 , at 98 . Sullivan stresses that a view of affirmative action that looks forward to the desired goal of an integrated society is preferable to the Court's current focus on past wrongful conduct.

${ }^{118}$ See, e.g., Daly, supra note 49, at 57 (underscoring Congress's concern, in enacting the Givil Rights Act of 1964, with "the dismal political and social predicament of blacks as well as their economic straits," stating that "[t]hrough various mechanisms of federal enforcement, Congress intended to end the status of blacks as this country's perpetual underling via the opening of political, social and economic vistas previously closed" and concluding that "[a]ccordingly, Title VII should be examined organically, not functionally, by the courts"); Fiss, A Theory of Fair Employment Laws, 38 U. CHI. L. REv. 235, 313 (1971) ("The essential quality of the antidiscrimination prohibition as applied to employment decisions is not color blindness."); Wright, Color-Blind Theories and Color-Conscious Remedies, 47 U. CHI. L. REV. 213, 245 (1980) ("It is time to abandon the abstractions of a 'color-blind' approach to achieving racial equality.").

110 See, e.g., Schnapper, Affirmative Action and the Legislative History of the 
inappropriate if it serves to defeat the broad remedial goal of achieving a society in which the effects of racial discrimination are no impediment to equality of opportunity. ${ }^{120}$

The Court's treatment of proof of harm as a predicate for remedy is rendered nonneutral by the manner in which the Court allocates the burden of proving that harm. Stotts established that minority employees defending an affirmative action program against a challenge by nonminority employees must be able to prove prior harm to the individuals being benefitted by the affirmative action or their claim for effective

Fourteenth Amendment, 71 VA. L. REv. 753, 754 (1985) ("The race-conscious Reconstruction programs were enacted concurrently with the fourteenth amendment and were supported by the same legislators. . . . This history strongly suggests that the framers of the amendment could not have intended it generally to prohibit affirmative action . . . "); Tribe, In What Vision of the Constitution Must the Law Be Color-Blind?, 20 J. Marshall L. Rev. 201, 204 (1986) (The race-neutralist reading of the Constitution encounters a major obstacle: "[W]e know . . . that the Framers of the Fourteenth Amendment did not think 'equal protection of the laws' made all racial distinctions in law unconstitutional; they did not intend, for example, to outlaw racially segregated public schools.").

120 The major cases grappling with the scope of the Court's remedial authority under Title VII have not settled on a final interpretive mode. Some of the cases strongly express the belief that Title VII should be construed liberally in light of its prophylactic purposes. See, e.g., Franks v. Bowman Transp. Co., 424 U.S. 747, 774-75 (1976) ("DD]enial of seniority relief to identifiable victims of racial discrimination on the sole ground that such relief diminishes the expectations of other, arguably innocent, employees would if applied generally frustrate the central 'make whole' objective of Title VII."; Albemarle Paper Co. v. Moody, 422 U.S. 405, 417 (1975)) ("[T]he primary objective [of Title VII] was a prophylactic one: 'It was to achieve equality of employment opportunities and remove barriers that have operated in the past to favor an identifiable group of white employees over other employees.' " (quoting Griggs v. Duke Power Co., 401 U.S. 424, $429-30$ (1971)); cf. County of Washington v. Gunther, 452 U.S. 161, 170, 178 (1981) (stating that Title VII should be read braadly to permit a cause of action for wage discrimination on the basis of sex despite the limiting language of the Bennett amendment, 42 U.S.C. $2000 \mathrm{E}(2)(\mathrm{h})(1982)$ ).

Additionally, United Steelworkers v. Weber, 443 U.S. 193 (1979), lends strong support to the notion that Title VII should not be read to inhibit parties from engaging in programs that further the goal of eradicating racial discrimination in the workplace. Even the cases that reveal a more limited view of the scope of the Court's remedial power under Title VII do not ignore the fact that Title VII was adopted by Congress as a measure to remedy the historical effects of racial discrimination. See, e.g., International Bhd. of Teamsters v. United States, 431 U.S. 324, 353-54 (1977) (holding that "an otherwise neutral, legitimate seniority system does not become unlawful under Title VII simply because it may perpetuate pre-Act discrimination."). Commentators such as Daly have exhaustively analyzed the legislative history and the cases and argue persuasively that a non-neutral reading of Title VII is mandated. See, e.g., Daly, supra note 49, at 22-23,101-02. Even the limiting principle of harm to whites in the layoff context cautiously proposed by Fallon \& Weiler, supra note 112 at $65-68$, has been rejected by the Court in the Title VII context, though their logic was influential in Wygant. See Wygant, $106 \mathrm{~S}$. Ct. at 1851-52. In light of the strong evidence that Title VII should not be read neutrally, this Comment will argue that procedural devices and remedies under the auspices of Title VII, even if they are to be administered neutrally, must not substantively contravene the overall goals of Title VII. 
relief fails entirely. In Regents of the University of California $v$. $B a k k e,{ }^{121}$ when initially faced with the question of reverse discrimination, the Court, after deciding that the quota system in question entailed an impermissible use of racial factors, assigned the burden of proving that the plaintiff was not harmed to the university. ${ }^{122}$ In both cases, the arbitrary allocation of the burden of proof is effectively dispositive in a manner that ignores the merits of either case. A strictly neutral stance would require that plaintiffs in both types of cases bear the same burden.

Yet, equalizing this treatment is not a purely neutral act. Victims in reverse discrimination suits, particularly if layoffs are involved, will usually be in a better position to prove harm because the discrimination from which they suffer is so self-contained. The only tangible benefit that such equalization provides for plaintiffs in an original discrimination case is that if they can avoid litigation through a consent decree or other voluntary arrangement with the employer, then the burden will be cast on the plaintiff in any potential reverse discrimination suit. In that situation, if hiring quotas rather than layoffs are involved, this burden might prove difficult for putative victims to prove, and the voluntary agreement may survive attack. ${ }^{123}$

The Court's treatment also appears nonneutral in another respect, for the principle of strict neutrality would require that the principles of Local 28 of the Sheet Metal Workers' International Association $v$. ${ }^{E E O C C^{124}}$ apply to both types of cases. Thus plaintiffs in reverse discrimination suits would have to show egregious intentional conduct in order to qualify for relief absent a showing of individual harm. Again, this would vindicate the Court's solicitude for victims of layoffs, but would properly insulate plans involving hiring quotas from attack by disgruntled, unsuccessful, white job applicants because, like Bakke, their chances of proving that they had been rejected in favor of less qualified minority applicants would be slim. ${ }^{125}$

Since reverse discrimination suits only arise after an employer has taken some form of remedial action, the task of meeting the burden of proof will fall initially on the plaintiffs in the initial discrimination

121438 U.S. 265 (1978).

${ }^{122}$ Id. at 320 (Powell, J., plurality).

123 This, in essence, is the complicated result dictated by a juxtaposed reading of Local 93 and Wygant. See supra notes 109-112 and accompanying text.

121106 S. Ct. 3019 (1986).

${ }^{128} \Lambda$ neutral rule would also seem to require reverse discrimination plaintiffs such as Wygant to bear exactly the same burdens discrimination plaintiffs bear in establishing liability, but this Comment is concerned only with the application of rules at the remedial phase of the proceeding. 
suits, that is, unless the affirmative action is taken pursuant to a voluntary agreement or a consent decree. ${ }^{126}$ This natural sequence exposes another aspect of the hidden bias in a seemingly neutral rule, and the problem is exacerbated by the Wygant Court's analytic focus on the minority teachers' failure to establish the necessary factual predicate, without placing any affirmative burden on the actual plaintiff. ${ }^{127}$

Given these inequities, perhaps the ad hoc decision in Bakke to shift the burden of proving harm to the defendant provides a fairer approach to framing a neutral rule. The language of section 706(g) supports such a reading: the proviso that make-whole relief is not required for persons against whom adverse actions were taken for some reason "other than discrimination"128 could be read as affording the employer the opportunity provided to the university in Bakke to prove that the claimant was not deserving of admission. ${ }^{120}$

Reasoning by analogy, this approach finds support in another employment discrimination context, the treatment of violations of the NLRA, section 8(a)(3). ${ }^{130}$ Faced with the difficulty of distinguishing an employer's purpose to discriminate against protected organizational conduct from its reasonable business justifications, the NLRB has established a procedural framework for handling such cases:

Initially, the General Counsel must establish a prima facie case that protected conduct was "a motivating factor" in the employer's decision. The burden then shifts to the employer to demonstrate, as an affirmative defense, that the decision would have been the same even in the absence of protected conduct. If the employer fails to establish the affirmative defense, the General Counsel will prevail, regardless of the quantum of unlawful motivation involved. If the employer does establish this defense, it would appear that the General Counsel would have the opportunity to rebut it. Absent such

${ }^{126}$ Both Local No. 93, International Ass'n of Firefighters v. City of Cleveland, 106 S. Ct. 3063 (1986), and United Steelworkers v. Weber, 443 U.S. 193 (1979), are meaningless unless they permit plaintiffs to escape the burden of proving either intention or disproportionate impact as a predicate to relief.

${ }_{127}$ See Wygant, 106 S. Ct. at 1849 \& n.5. Even though the school board was willing to stipulate that it had been guilty of prior discrimination, the Court held that such discrimination had to be established in a judicial proceeding. Following this logic, a voluntary agreement cannot be effectuated without going through the litigation that the parties sought to avoid.

${ }_{128}^{128} 42$ U.S.C. \& $2000 \mathrm{e}-5(\mathrm{~g})(1982)$.

${ }^{128}$ See Bakke, 438 U.S. at 320 . International Bhd. of Teamsters v. United States, 431 U.S. 324 (1977), and Stotts indicate that the Court has broadened the previously narrow reading of $\S 703(h)$. See Note, supra note 44 , at 263-64, 268-69.

${ }_{130}$ NLRA, 29 U.S.C. \& 158(a)(3) (1982). See Spiegelman, supra note 49, at 378. 
rebuttal, the employer would prevail. ${ }^{131}$

Adopting such a framework in the Title.VII context would ameliorate the distorting effect of a neutral rule which puts the burden solely on the plaintiff as outlined above. Presumably, few employers will wish to spend the time and money required to prove that individual plaintiffs were not harmed. The propriety of extending this framework to Title VII remedial problems follows from the fact that a similar analytical structure has been applied in Title VII cases at the liability stage. ${ }^{\mathbf{1 3 2}}$ The objection that this changed context provides adequate justification to counsel against the shifting of the burden of proof to the defendant, as adopted at the liability stage, can be dismissed. Indeed, the fact that liability has already been established at the remedial phase would tend to suggest that the employer's burden be greater than the plausible business justification required to defeat the presumption raised by the plaintiff. ${ }^{133}$ Once liability has been established, the defendant has no equitable claim to a procedural shield thát would nullify the finding of liability.

Certainly, reading section $706(\mathrm{~g})$ as requiring this shifting of burden gives the Court more power to fashion effective remedies for discrimination under Title VII, while the Stotts reading clearly frustrates this overarching prophylactic purpose. ${ }^{134}$ Despite the invocation in

131 A. Cox, D. BoK \& R. Gorman, Cases and Materials on Labor Law 233 (9th ed. 1981) (quoting NLRB Memorandum 80-58). See also Mount Healthy City School Dist. Bd. of Educ. v. Doyle, 429 U.S. 274, 287 (1977) ("Initially, . . . the burden was properly placed upon respondent to show that his conduct ... was a 'motivating factor' in the Board's decision not to rehire him. Respondent having carried that burden, however, the District Court should have gone on to determine whether the Board had shown by a preponderance of the evidence that it would have reached the same decision . . . even in the absence of the protected conduct."); Wright Line, Inc., 251 N.L.R.B. 1083, 1089 (1980) (setting forth the following "causation test" for alleging a violation of $\S 8(\mathrm{a})(3)$ : "First, we shall require that the General Counsel make a prima facie showing sufficient to support the inference that protected conduct was a 'motivating factor' in the employer's decision. Once this is established, the burden will shift to the employer to demonstrate that the same action would have taken place even in the absence of the protected conduct.").

${ }^{132}$ See, e.g., Texas Dep't of Community Affairs v. Burdine, 450 U.S. 248, 253 (1981) (requiring employer to advance some evidence of nondiscriminatory motive once the plaintiff in a disparate treatment suit under Title VII has made out a prima facie case).

${ }^{133}$ The defendant's burden in Burdine is slight; "[i]t is sufficient if the defendant's evidence raises a genuine issue of fact as to whether it discriminated against the plaintiff." Id. at 253-256. This is in keeping with the notion that the burden of persuasion that a discriminatory situation exists remains on the plaintiff as regards liability. Id. at 253. Given this structure of alternating the burden of proof, it would be conceptually consistent to shift the burden back to the defendant once liability has been established.

134 See supra note 122 and accompanying text. 
Stotts of a number of decisions from the mid-seventies ${ }^{\mathbf{1 3 5}}$ dealing with the Court's remedial authority under Title VII, a reading of those cases lends more support to interpretations of Title VII that focus on its vitality and ability to reach a myriad of complex situations in which discrimination is manifest. ${ }^{138}$ Of course, if neutrally applied, this burden shift would theoretically enable reverse discrimination plaintiffs to challenge hiring quotas on the basis of their class status as effectively as they can currently challenge layoffs. Since Wygant has already established a constitutional cause of action for reverse discrimination ${ }^{\mathbf{1 3 7}}$ and since the Court has not held reverse discrimination plaintiffs to the same standards of proof imposed in Stotts, this additional advantage to reverse discrimination plaintiffs is outweighed by the advantage gained by minority plaintiffs who face the practical procedural disadvantages sketched previously. ${ }^{138}$ In short, shifting the burden of proving harm away from the plaintiff at the remedial stage of a Title VII action is the rule that serves to put the two types of plaintiffs on the most equal footing. Since the choice of an abstractly neutral approach inevitably has practical consequences which are substantively nonneutral, the Court should choose the rule which is most equal in practice. In this case the choice of that particular reading is reinforced by the fact that it furthers the most important purpose of Title VII, which is to provide a vehicle for eliminating discrimination in the workplace. ${ }^{139}$

\section{CONCLUSION}

The cases discussed herein reveal the Court's attempt to integrate traditional judicial notions of its remedial power with the rather broad statutory and constitutional mandates in order to fashion effective remedies for discrimination. When, as is the case with affirmative action, remedial devices go beyond monetary compensation and involve restructuring relations among large groups and institutions, the problem of administering simple justice becomes complex indeed.

The decisions discussed in this Comment will do little to dispel the complexity or settle the law. Although Local 28 of the Sheet Metal Workers International Association v. EEOC ${ }^{140}$ allows courts to issue class-based relief without a showing of individual harm, it is far from

135 International Bhd. of Teamsters v. United States, 431 U.S. 324 (1977); Franks

v. Bowman Transp. Co., 424 U.S. 747 (1976). See supra note 120.

${ }^{138}$ See Daly, supra note 49 , at $17-55$.

197 Wygant, 106 S. Ct. 1842, 1846 (1986)

${ }_{138}$ See supra text accompanying notes 124-28.

138 See Daly, supra note 49, at 102.

140106 S. Ct. 3019 (1986). 
clear what constitutes the sort of egregious, intentional conduct that will justify such relief. Absent such a showing it seems that the principles set forth in Firefighters Local Union, No. 1784 v. Stotts ${ }^{141}$ still have force. It is also clear that Local No. 93, International Association of Firefighters $v$. City of Cleveland ${ }^{\mathbf{1 4 2}}$ leaves plaintiffs free to pursue settlements and consent decrees without being bound by the Stotts interpretation of Title VII. However, Stotts may still constrain the ability of courts to modify those decrees should changed circumstances blunt their effectiveness; thus, careful drafting is still the best hedge against uncertainty.

Even if these decisions indicate that Stotts is to be given little force within the context of Title VII jurisprudence, the remedial attitude adopted in Stotts has gained constitutional force through its incorporation into equal protection doctrine in Wygant. ${ }^{143}$ Thus, affirmative action programs instituted by state actors are now subject to challenge. Wygant itself leaves several issues open, most notably whether an intent to eliminate past discrimination can be a compelling state interest. Certainly, an exploration of the limits of Wygant similar to that undertaken vis-à-vis Stotts can be expected in the near future. Throughout these cases, the Court's methodology has been to deal with the issues indirectly, through procedural devices such as the allocation of the burden of proof, or through semantic distinctions such as the difference between the entry and modification of consent decrees. This indirection contributes significantly to the complexity of the doctrinal formulations that emerge from the decisions. Perhaps by removing the quota system/ layoff debate to the constitutional level, the Court is moving toward a simpler, more direct look at the question of affirmative action, free from the statutory and case law ambiguities of Title VII. If so, some stability may be achieved. If not, a clearer legislative directive may be needed to untangle the knots.

141467 U.S. 561 (1984).

142106 S. Ct. 3063 (1986).

14 Wygant v. Jackson Bd. of Educ., 106 S. Ct. 1842, 1846 (1986). 